\title{
Distribution of T-lymphocytes in follicular lymphomas as revealed by acid $\alpha$-naphthol acetate esterase
}

\author{
CONSTANTIN S. PAPADIMITRIOU AND NIKOLAOS X. PAPACHARALAMPOUS
}

From the Department of Pathology (Pathologikon Anatomion), University of Athens, Athens (Goudi) 617, Greece

SUMMARY Twelve cases of follicular centroblastic/centrocytic malignant lymphoma were studied for acid non-specific esterase. The majority of the lymphocytes in interfollicular areas showed a pattern of enzymatic activity consistent with a T-cell nature. Variable numbers of lymphocytes with a similar enzymatic pattern were also seen among the negative centroblasts and centrocytes in neoplastic follicles.

Follicular malignant lymphomas are now considered to be of germinal centre origin (Lennert, 1973; Jaffe et al., 1974; Leech et al., 1975; Lennert 1978; Lukes and Collins, 1975; Stein et al., 1978a). However, in studies of cell surface markers and T-lymphocyte antigen, they appear to contain significant numbers of T-cells (Aisenberg and Long, 1975; Brouet et al., 1975; Jaffe et al., 1975; Leech et al., 1975). Their distribution in lymphomatous tissue has as yet been poorly defined. As EACrosette studies on frozen sections (Jaffe et al., 1974; Stein et al., 1978b) indicate, it seems possible that the majority of the lymphoid cells in internodular areas are T-cells.

Acid non-specific esterase, introduced as a T-cell marker in experimental animals by Müller $e t$ al. (1975), has also been proved to be quite valid in human reactive and neoplastic tissues (Kulenkampff et al., 1977).

We have studied the distribution of lymphoid cells showing an acid non-specific esterase activity identical with that shown by T-cells in histological sections from 12 cases of nodular germinal centre cell lymphomas.

\section{Material and methods}

Fresh biopsy material from 12 cases of follicular centroblastic-centrocytic malignant lymphoma was cut into thin slices and fixed immediately in buffered

Received for publication 23 January 1979 formol-sucrose (distilled water, $450 \mathrm{ml} ; 40 \%$ formaldehyde, $50 \mathrm{ml} ; 37.5 \mathrm{~g}$ sucrose; $\mathrm{NaH}_{2} \mathrm{PO}_{4} . \mathrm{H}_{2} \mathrm{O}$, $2 \mathrm{~g} ; \mathrm{Na}_{2} \mathrm{HPO}_{4} 3.25 \mathrm{~g}$ ) at $4^{\circ} \mathrm{C}$ for 24 hours. They were kept in Holt's solution (sucrose $\mathbf{3 0} \mathrm{g}$; gum arabic $\mathbf{1}$ g; distilled water $100 \mathrm{ml}$ ) for another 24 hours. Frozen sections of $5 \mu \mathrm{m}$ thickness were mounted onto slides pretreated with formol-gelatin. They were left to dry at room temperature for 1 hour and stained for non-specific acid esterase (Müller et al., 1975) as follows:

Solution A: 1 g pararosaniline, acridine-free, CI No. 42500 (Chroma, Stuttgart-Untertürkheim, Federal Republic of Germany) is dissolved in $20 \mathrm{ml}$ distilled water, and $4 \mathrm{ml}$ concentrated $\mathrm{HCl}$ is added. After gentle warming, cooling, and filtration store in the dark at $4^{\circ} \mathrm{C}$.

Solution B: Freshly prepared $4 \%$ aqueous solution of sodium nitrite.

Mix equal parts of solutions A and B. Shake for a few seconds until the colour becomes amber. Dissolve $10 \mathrm{mg} a$-naphthyl acetate (Sigma, USA) in $0.4 \mathrm{ml}$ acetone. Mix $40 \mathrm{ml} 0.067 \mathrm{M}$ phosphate buffer, pH 5 , and $2.4 \mathrm{ml}$ of hexazotised pararosaniline. Add substrate and adjust working solution to pH 5.8 using $2 \mathrm{~N} \mathrm{NaOH}$.

Incubate sections in working solution at room temperature for 2 hours. Wash in distilled water, counterstain slightly with methylgreen, dehydrate, and mount in Eukitt.

Another piece of each biopsy material was routinely processed for histological study. Paraffin sections were stained with haematoxylin and eosin, Giemsa stain, PAS-reaction, and Gomori's silver stain. 808 
Results

All cases showed histologically a well-developed nodular pattern. Interfollicular areas (Figs 1 and 2) were more or less prominent. They consisted mainly of small and medium-sized lymphocytes. Among them small numbers of plasma cells were found. In places venules of an epithelioid type were rec-

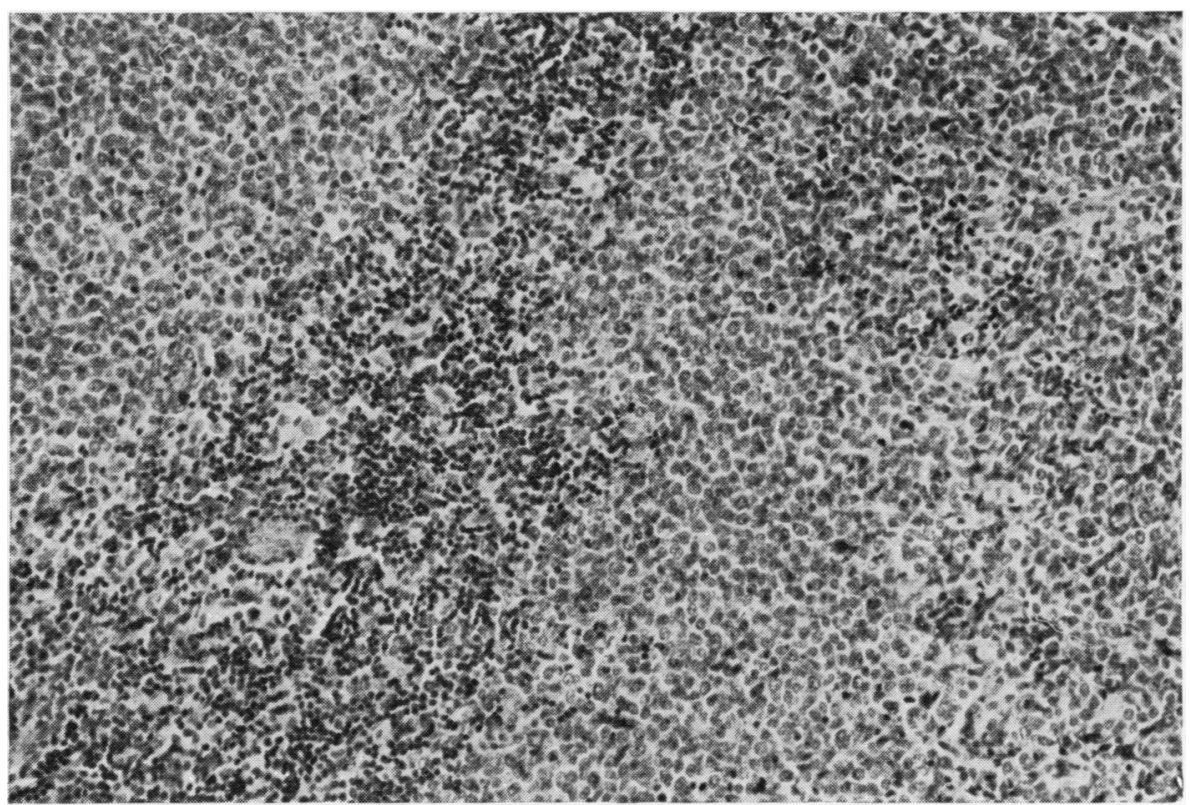

Fig. 1 A case of follicular lymphoma. Interfollicular area with small lymphocytes is moderately developed. Haematoxylin and eosin $\times 125$.

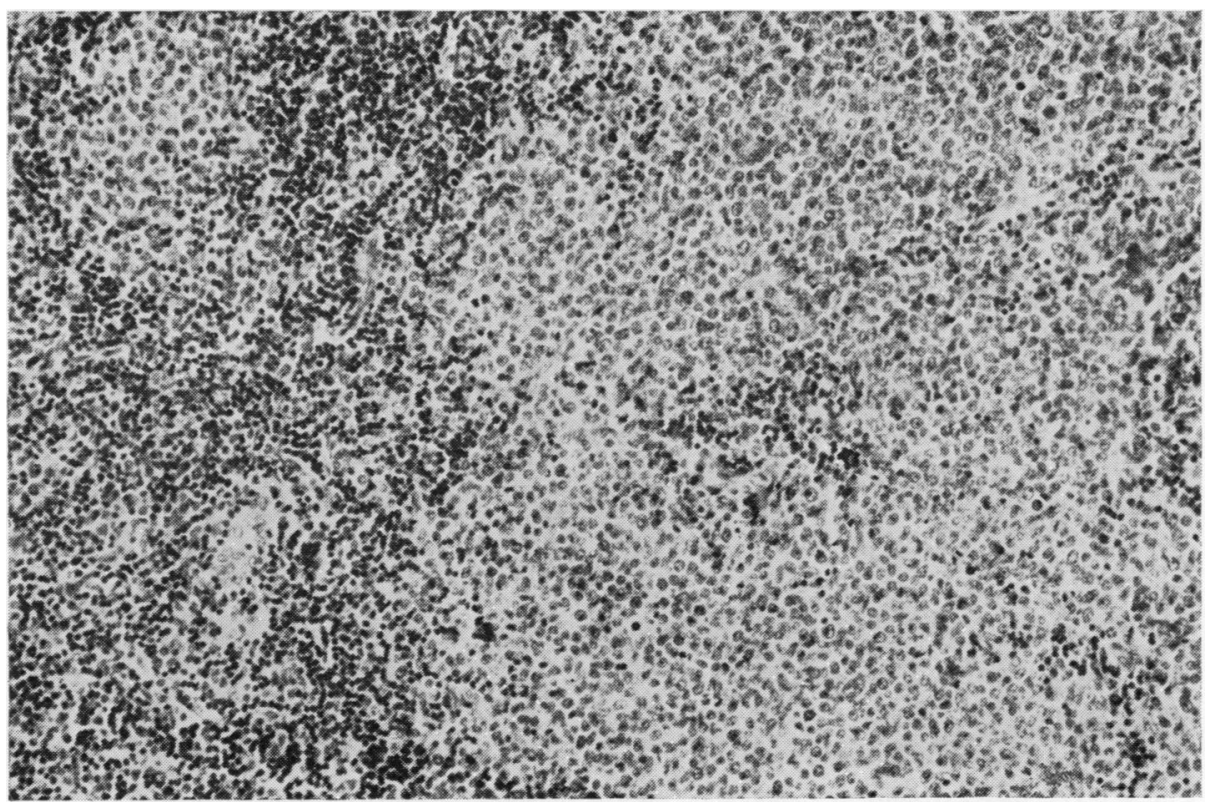

Fig. 2 Another case of follicular lymphoma. Interfollicular area appears to be hyperplastic.

Additionally, small lymphocytes are easily found inside the neoplastic follicles. $H$ and $E \times 125$. 
ognized. In four cases, hyperplasia of postcapillary venules was apparent. Neoplastic nodules consisted mainly of variable proportions of cells showing the features of centroblasts and centrocytes. In all cases among the neoplastic cells, small- and mediumsized lymphocytes resembling those of the interfollicular area were found. Their numbers varied from case to case and were greater at the periphery of the nodules and near small vessels (Fig. 2). In three cases, considerable numbers of basophilic cells showing a plasmacytoid configuration were found in neoplastic nodules. In one of the three cases such plasmacytoid cells were abundant at the periphery of and around the neoplastic nodules. In this particular case the number of small lymphocytes in interfollicular spaces was small. On the other hand, cells with a centrocytic appearance were present. Postcapillary venules were very scarce.

In frozen sections stained for acid non-specific esterase many lymphocytes in interfollicular areas showed a focal 'dot-like' positivity for the enzyme (Figs 3 and 4). Their relative numbers were usually more than $70 \%$ of the whole lymphocytic population in such areas (Table). In the single case with abundant plasmacytoid cells around the neoplastic nodules, lymphocytes with an analogous enzymatic reaction were rare. They were more abundant around the epithelioid venules which were oc-
Table Frequency of interfollicular lymphocytes with a 'dot-like' enzyme positivity in the 12 follicular lymphomas

\begin{tabular}{lllll}
\hline & \multicolumn{5}{l}{ Percent of positive lymphocytes } \\
\cline { 2 - 5 } & $<30$ & $30-50$ & $50-70$ & $>70$ \\
\hline Number of cases & 1 & 1 & 2 & 8 \\
\hline
\end{tabular}

casionally found. In neoplastic nodules centroblastic and centrocytic cells were negative for acid nonspecific esterase (Fig. 5). Among them, however, variable numbers of lymphocytes, corresponding apparently to those described in paraffin sections, showed a pattern of enzymatic reaction similar to that found in interfollicular lymphocytes (Fig. 6).

\section{Discussion}

Jaffe et al. (1974) found that in follicular lymphomas the areas that are mainly positive for EAC-rosettes are neoplastic nodules. Stein et al. (1978b), using in EAC-rosettes the subtypes C3d and C3b, have shown that neoplastic follicles are $\mathrm{C} 3 \mathrm{~d}$ and $\mathrm{C} 3 \mathrm{~b}$ positive while in interfollicular areas cells positive for C3b only were found. However, such studies cannot offer direct evidence for the presence of T-cells. T-cell markers studied in cell suspensions

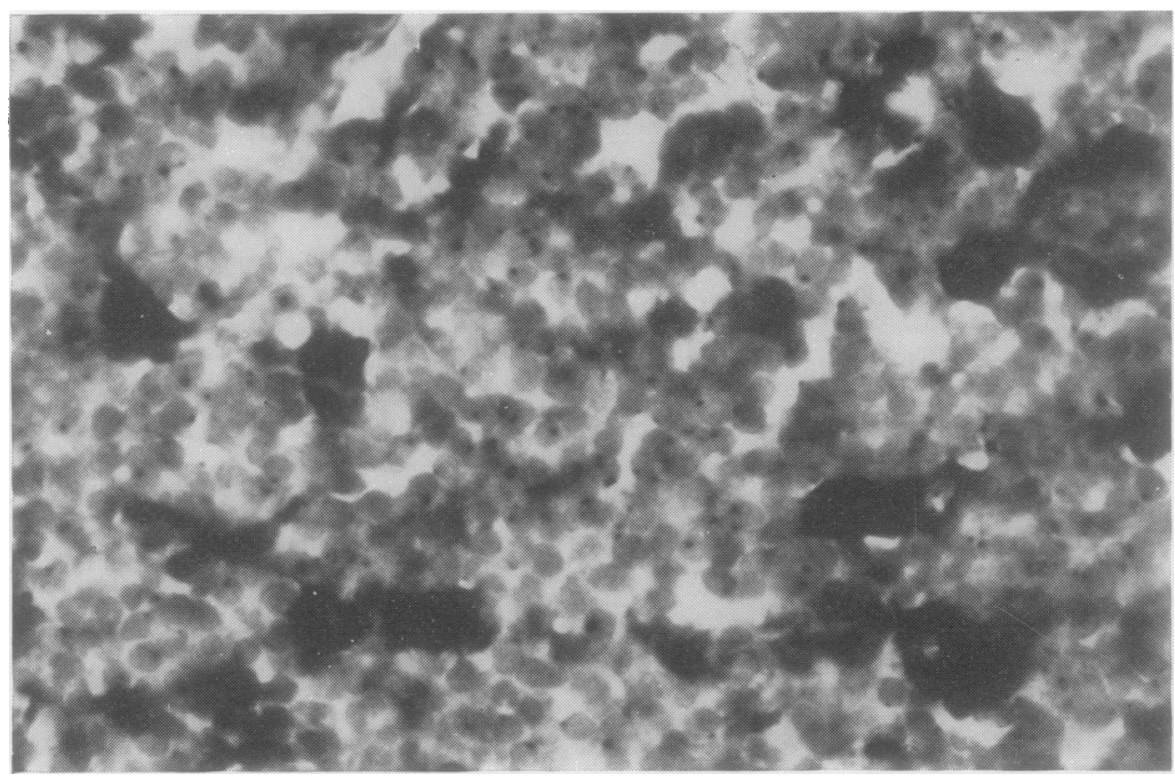

Fig. 3 'Dot-like' positivity of lymphocytes for non-specific esterase in interfollicular area of a follicular lymphoma. $\times 500$. 


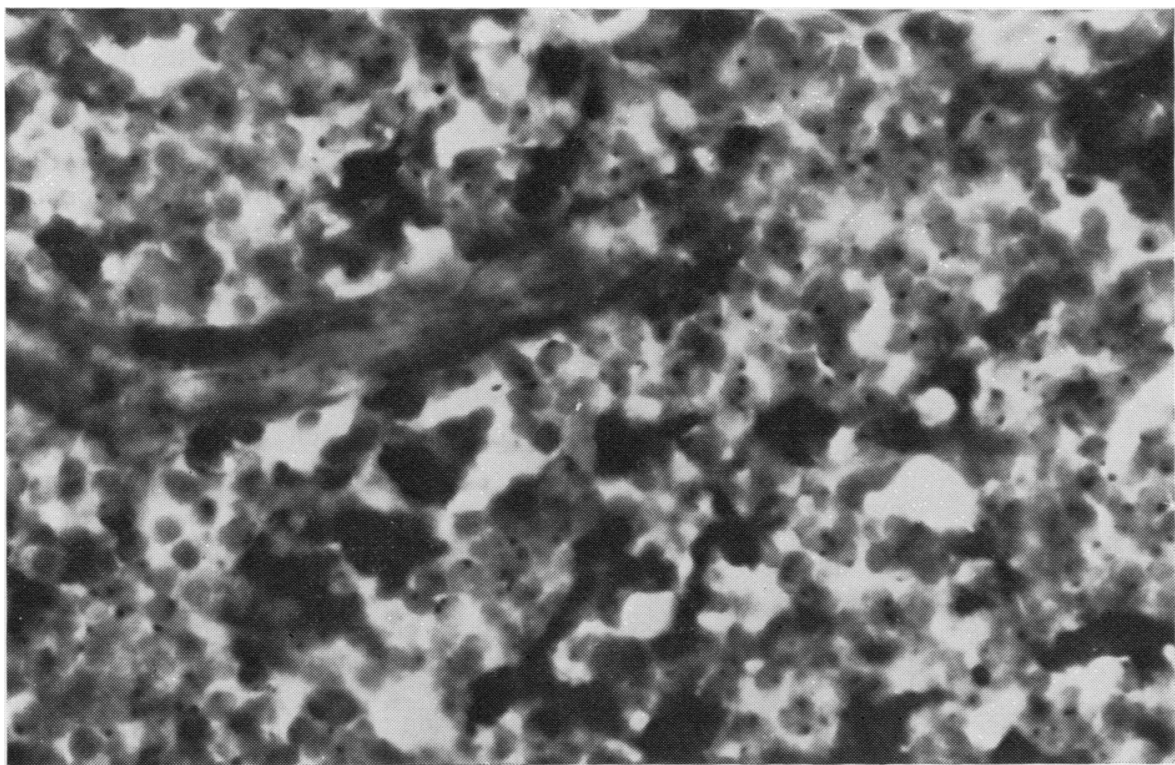

Fig. 4 The same enzyme pattern as in Fig. 3 found in interfollicular lymphocytes of another follicular lymphoma. $\times 500$.

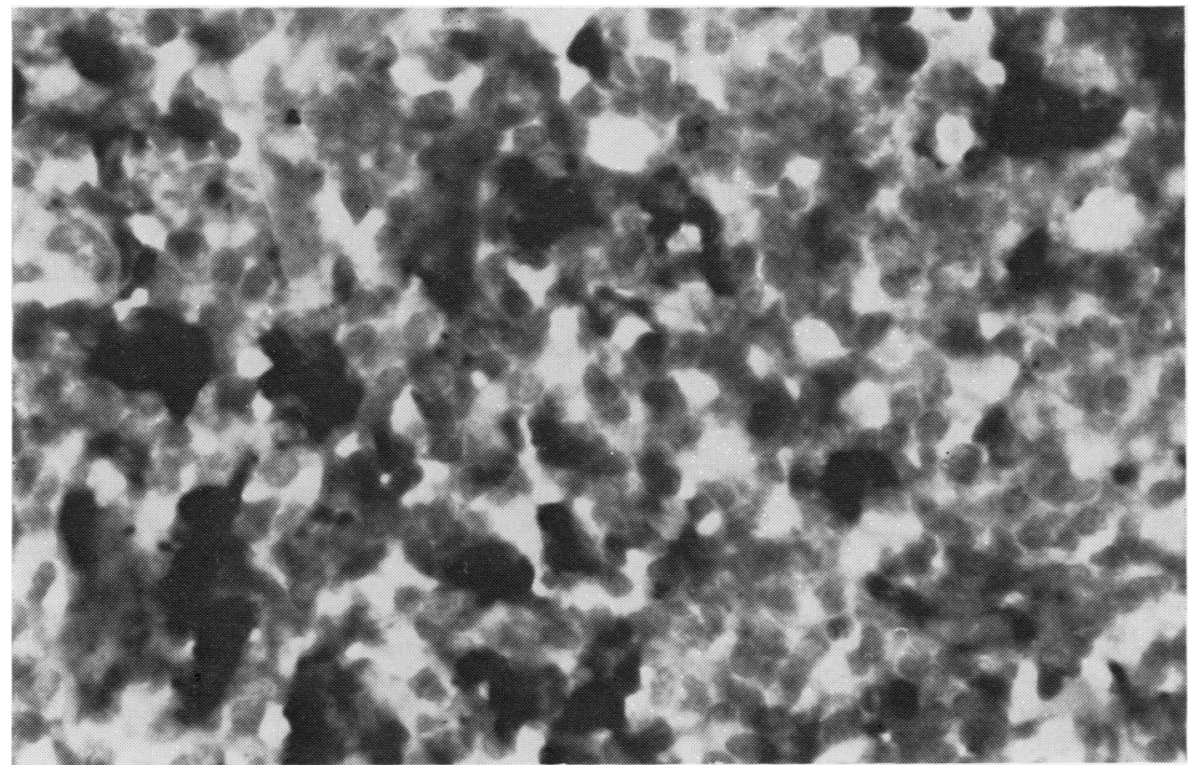

Fig. 5 Neoplastic follicular centre cells are negative for non-specific esterase. Follicular area of the same case as in Fig. 3. $\times 500$.

have shown that in some cases of follicular lymphoma the number of T-cells is as high as $82 \%$ of the whole cell population (Aisenberg and Long, 1975). Such observations support the view that nodular lymphomas, although rarely, could be of
T-cell origin. This view, however, is debatable so long as the nodular pattern could be attributed to follicular centre rests inside a T-cell neoplasm (Stein, 1978). As well as epithelioid venules, Kaiserling (1976) has found electron microscopically in 


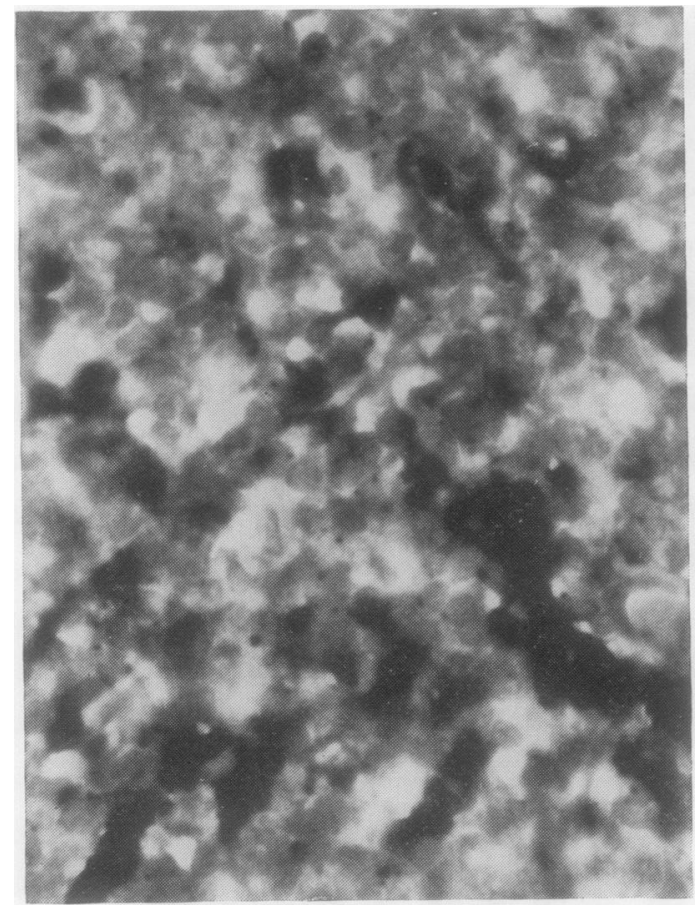

Fig. 6 Lymphocytes with a 'dot-like' enzyme positivity are found inside a nodule among neoplastic follicular centre cells. $\times 500$.

interfollicular areas of follicular lymphomas large numbers of interdigitating reticulum cells and socalled T-associated plasma cells. Accordingly, he assumes that this area represents a T-zone and the lymphocytes found there are presumably T-cells.

Our present series includes follicular lymphomas with the typical cytology of centroblastic/centrocytic malignant lymphomas (Lennert, 1978). Centroblasts and centrocytes were negative for acid non-specific esterase, a fact consistent with their B-cell nature. As the majority of the lymphocytes in interfollicular areas were focally positive for acid non-specific esterase, they must be considered to be of a T-cell nature. Accordingly, the areas containing them should represent a T-zone, as proposed electron microscopically by Kaiserling (1976). Such areas could generally be accepted as lymphatic tissue rests compressed between expanding neoplastic nodules. In four cases, however, they showed a true active hyperplasia. Whether T-zone hyperplasia represents an immunological reaction against neoplastic tissue or a non-neoplastic T-cell hyperplasia paralleling B-cell neoplasia cannot be stated at present. Ree and Leone (1978), however, have shown that in follicular lymphomas survival was closely related to the prominence of interfollicular areas.

Our finding of lymphocytes inside the neoplastic nodules showing an enzymatic activity consistent with a T-cell nature is of great importance and has not been described previously. It could indicate that the possible normal interaction between follicular centre cells and T-cells is preserved in neoplastic nodules also. Weissman et al. (1976), using anti-Bcell and anti-T-cell sera, have shown that in primary and secondary germinal centers a number of T-cells is always present. Additionally, Kelly and Wolstencroft (1974) have shown that germinal centre reaction is enhanced by $\mathrm{T}$-cell extracts.

\section{References}

Aisenberg, A. C., and Long, J. C. (1975). Lymphocyte surface characteristics in malignant lymphoma. American Journal of Medicine, 58, 300-306.

Brouet, J. C., Labaume, S., and Seligmann, M. (1975). Evaluation of T and B lymphocyte membrane markers in human non-Hodgkin malignant lymphomata. British Journal of Cancer, 31, Supplement 2, 121-127.

Jaffe, E. S., Shevach, E. M., Frank, M. M., Berard, N. C., and Green, I. (1974). Nodular lymphoma-evidence for origin from follicular B lymphocytes. New England Journal of Medicine, 290, 813-819.

Jaffe, E. S., Shevach, E. M., Sussman, E. H., Frank, M., Green, I., and Berard, C. W. (1975). Membrane receptor sites for the identification of lymphoreticular cells in benign and malignant conditions. British Journal of Cancer, 31, Supplement 2, 107-120.

Kaiserling, E. (1976). Elektronmikroskopische Befunde bei non-Hodgkin-Lymphome. In Maligne Lymphome und monoklonale Gammopathien. Hämatologie und Bluttransfusion, edited by H. Löffler, Vol. 18, pp. 185198. Lehmans, Munich.

Kelly, R. H., and Wolstencroft, R. A. (1974). Germinal centre proliferation in response to mitogenic lymphokines. Clinical and Experimental Immunology, 18, 321-336.

Kulenkampff, J., Janossy, G., and Greaves, M. F. (1977). Acid esterase in human lymphoid cells and leukaemic blasts: a marker for T lymphocytes. British Journal of Haematology, 36, 231-240.

Leech, J. H., Glick, A. D., Waldron, J. A., Flexner, J. M., Horn, R. G., and Collins, R. D. (1975). Malignant lymphomas of follicular center cell origin in man. I. Immunologic studies. Journal of the National Cancer Institute, 54, 11-21.

Lennert, K. (1973). Follicular lymphoma. A tumor of the germinal centers. Gann Monographs on Cancer Research, 15, 217-231.

Lennert, K. (1978). Malignant Lymphomas other than Hodgkin's Disease. Springer, Berlin, Heidelberg, New York.

Lukes, R. J. and Collins, R. D. (1975). New approaches to the classification of the lymphomata. British Journal of Cancer, 31, Supplement 2, 1-28. 
Müller, J., Brun del Re G., Buerki, H., Keller, H. U., Hess, M. W., and Cottier, H. (1975). Nonspecific acid esterase activity: a criterion for differentiation of $\mathbf{T}$ and B lymphocytes in mouse lymph nodes. European Journal of Immunology, 5, 270-274.

Ree, H. J., and Leone, L. A. (1978). Prognostic significance of parafollicular small lymphocytes in follicular lymphoma. Cancer, 41, 1500-1510.

Stein, H. (1978). The immunologic and immunochemical basis for the Kiel classification. In Malignant Lymphomas Other than Hodgkin's Disease, edited by $\mathrm{K}$. Lennert, pp. 529-657. Springer, Berlin, Heidelberg, New York.

Stein, H., Papadimitriou, C. S., Bouman, H., Lennert, K., and Fuchs, J. (1978a). Demonstration of immunoglobulin production by tumor cells in non-Hodgkin's and Hodgkin's malignant lymphomas and its signif:cance for their classification. Recent Results in Cancer Research, 64, 158-175.

Stein, H., Siemssen, U., and Lennert, K. (1978b). Complement receptor subtypes $\mathrm{C} 3 \mathrm{~b}$ and $\mathrm{C} 3 \mathrm{~d}$ in lymphatic tissue and follicular lymphoma. British Journal of Cancer, 37, 520-529.

Weissman, I. L., Gutman, G. A., Friedberg, S. H., and Jerabek, L. (1976). Lymphoid tissue architecture. III. Germinal centers, $T$ cells, and thymus-dependent vs. thymus-independent antigens. Advances in Experimental Medicine and Biology, 66, 229-237.

Requests for reprints to: Dr C. S. Papadimitriou, Department of Pathology, University of Athens, Athens (GOUDI) 617, Greece. 